\title{
The Emerging Role of Innate Immunity in Chronic Kidney Diseases
}

\author{
Philip Chiu-Tsun Tang ${ }^{1,+}{ }^{\oplus}$, Ying-Ying Zhang ${ }^{2,+}$, Max Kam-Kwan Chan ${ }^{1}$, \\ Winson Wing-Yin Lam ${ }^{1}$, Jeff Yat-Fai Chung ${ }^{1}$, Wei Kang ${ }^{1}{ }^{\circledR}$, Ka-Fai To ${ }^{1}$, Hui-Yao Lan ${ }^{3}[$ and \\ Patrick Ming-Kuen Tang ${ }^{1, *}$ \\ 1 Department of Anatomical and Cellular Pathology, State Key Laboratory of Translational Oncology, \\ Prince of Wales Hospital, The Chinese University of Hong Kong, Hong Kong 999077, China; \\ philtang@link.cuhk.edu.hk (P.C.-T.T.); kamkwanchan@cuhk.edu.hk (M.K.-K.C.); \\ jeffchung@link.cuhk.edu.hk (J.Y.-F.C.); wingyinlam@cuhk.edu.hk (W.W.-Y.L.); weikang@cuhk.edu.hk (W.K.); \\ kfto@cuhk.edu.hk (K.-F.T.) \\ 2 Department of Nephrology, Tongji Hospital, Tongji University School of Medicine, Shanghai 200065, China; \\ idklaa@hotmail.com \\ 3 Li Ka Shing Institute of Health Sciences, and Department of Medicine \& Therapeutics, \\ The Chinese University of Hong Kong, Hong Kong 999077, China; hylan@cuhk.edu.hk \\ * Correspondence: patrick.tang@cuhk.edu.hk \\ $\dagger$ These authors contributed equally to this work.
}

Received: 1 April 2020; Accepted: 2 June 2020; Published: 4 June 2020

\begin{abstract}
Renal fibrosis is a common fate of chronic kidney diseases. Emerging studies suggest that unsolved inflammation will progressively transit into tissue fibrosis that finally results in an irreversible end-stage renal disease (ESRD). Renal inflammation recruits and activates immunocytes, which largely promotes tissue scarring of the diseased kidney. Importantly, studies have suggested a crucial role of innate immunity in the pathologic basis of kidney diseases. This review provides an update of both clinical and experimental information, focused on how innate immune signaling contributes to renal fibrogenesis. A better understanding of the underlying mechanisms may uncover a novel therapeutic strategy for ESRD.
\end{abstract}

Keywords: chronic kidney disease; microenvironment; kidney fibrosis; macrophage-myofibroblast transition; inflammation

\section{Introduction}

Chronic kidney disease (CKD) is an emerging cause of morbidity and mortality worldwide. The global estimated prevalence of CKD is $13.4 \%$ (11.7\%-15.1\%) [1], affecting $26-30$ million adults in the United States [2], 120 million adults in China, and causing renal replacement of 4.902 to 7.083 million patients. CKD defines as abnormalities of kidney structure or function caused by primary and secondary glomerular diseases, including glomerulonephritis, hypertension, and diabetic mellitus [3,4]. Notably, effective CKD treatment is still unavailable.

Glomerulosclerosis and tubulointerstitial fibrosis are core manifestations of CKD, considered as the common fate of most chronic and progressive nephropathies toward end-stage renal disease (ESRD). In glomerulosclerosis, mesangial and endothelial cells play an important role in extracellular matrix (ECM) production by forming myofibroblasts [5]. In contrast, renal tubular epithelial cells and infiltrating immunocytes largely contribute to the ECM formation in tubulointerstitial fibrosis [6-10]. It is conceivable that glomerulosclerosis and tubulointerstitial fibrosis share similar disease mechanisms with minor differences. In general, collagen type IV deposits in the mesangial interstitial space and manifests as nodular changes in the glomeruli, whereas collagen type I deposits and manifests as 
diffuse changes in the tubulointerstitium [11]. To our knowledge, rare nephropathy initially presents glomerulosclerosis without interstitial fibrosis. Although the development of glomerular inflammation precedes interstitial fibrosis, tubulointerstitial fibrosis appears to be a uniform feature of progressive nephropathy, which best predicts renal failure [12].

Despite the number of causes, emerging evidence shows that renal inflammation plays a central role in the progression of kidney fibrosis [13-16]. The pro-fibrotic mechanisms of host immunity have been uncovered, contributing to the development of effective anti-fibrotic strategies. In this review, we summarized the updates of innate immunity in renal pathogenesis and their therapeutic implications in CKD (Table 1).

Table 1. Summary of the role of innate immune cells in the pathogenesis of kidney diseases.

\begin{tabular}{|c|c|c|c|}
\hline Diseases & Models & Role of Inflammatory Cells & Ref. \\
\hline \multicolumn{4}{|c|}{ Neutrophils } \\
\hline AKI & Renal I/R injury & $\begin{array}{l}\text { Neutrophils release extracellular DNA (NET) to } \\
\text { stimulate inflammation via toll-like receptor } \\
\text { signaling and platelet activation. }\end{array}$ & [17] \\
\hline AKI & Renal I/R injury & $\begin{array}{l}\text { Neutrophils induce tubular necrosis via } \\
\text { PAD-mediated NET formation }\end{array}$ & [18] \\
\hline Glomerulo-nephritis & $\begin{array}{l}\text { Anti-GBM } \\
\text { Nephritis }\end{array}$ & $\begin{array}{l}\text { Histones released by neutrophils induce } \\
\text { glomerular vascular injury by direct killing of } \\
\text { endothelial cells }\end{array}$ & {$[19,20]$} \\
\hline \multicolumn{4}{|c|}{ Dendritic cells } \\
\hline $\begin{array}{l}\text { Focal segmental } \\
\text { glomerulo-sclerosis }\end{array}$ & $\begin{array}{l}\text { Adriamycin } \\
\text { nephropathy }\end{array}$ & $\begin{array}{l}\mathrm{CD} 103^{+} \text {dendritic cells activate CD } 8^{+} \mathrm{T} \text { cells to } \\
\text { induce apoptosis of tubular epithelial cells and } \\
\text { inflammatory cytokines (TNF- } \alpha \text { and IFN- } \gamma \text { ) } \\
\text { release. }\end{array}$ & {$[21,22]$} \\
\hline \multicolumn{4}{|c|}{ Natural killer cells } \\
\hline Lupus nephritis & $\begin{array}{l}\mathrm{MRL} / \mathrm{MpJ} \\
\mathrm{MRL} / \mathrm{lpr} \text { mice }\end{array}$ & $\begin{array}{l}\text { Infiltrated NK cells secret IFN- } \gamma \text { to promote renal } \\
\text { inflammation }\end{array}$ & [23] \\
\hline AKI & Renal I/R injury & $\begin{array}{l}\text { Activated NK cells induce kidney injury via } \\
\text { attacking tubular epithelial cells }\end{array}$ & {$[24]$} \\
\hline \multicolumn{4}{|c|}{ Macrophages } \\
\hline $\begin{array}{l}\text { Crescentic } \\
\text { glomerulonephritis }\end{array}$ & $\begin{array}{l}\text { Anti-GBM } \\
\text { Nephritis }\end{array}$ & $\begin{array}{l}\text { Macrophages express pro-inflammatory } \\
\text { molecules (tumor necrosis factor, MMP-12, CCL2, } \\
\text { and IL-12) in crescentic injury. }\end{array}$ & {$[25,26]$} \\
\hline Renal fibrosis & $\begin{array}{l}\text { Unilateral Ureter } \\
\text { Obstruction }\end{array}$ & $\begin{array}{l}\text { Alternative activated macrophage produces } \\
\text { pro-fibrotic molecules (MMPs and Galectin 3) for } \\
\text { the development of renal fibrosis }\end{array}$ & {$[27,28]$} \\
\hline Renal fibrosis & $\begin{array}{l}\text { Unilateral Ureter } \\
\text { Obstruction } \\
\text { Kidney } \\
\text { Trans-plantation }\end{array}$ & $\begin{array}{l}\text { Alternative activated macrophage further transits } \\
\text { into } \alpha \text {-SMA }{ }^{+} \text {collagen-producing myofibroblast } \\
\text { for extensive extracellular matrix deposition }\end{array}$ & [29-31] \\
\hline
\end{tabular}

\section{Inflammatory and Fibrotic Pathways in CKD}

\subsection{Inflammatory Pathway}

\subsubsection{NF- $\mathrm{kB}$ Signaling}

The NF- $\mathrm{kB}$ protein complex is the central regulator of the intricate inflammatory pathway network, responsible for the transcription of multiple inflammatory genes related to immunity, apoptosis, cell proliferation, and differentiation [32]. A systemic increase in inflammatory cytokines (IL-1 $\beta$, TNF- $\alpha$, LPS) activates NF- $\kappa B$ signaling associated with low-grade inflammation and chronic diseases, including CKD [33]. TNF- $\alpha$ and IL-1 $\beta$ interact with their respective receptors (TNFR1, IL-1R1) to activate NF- $\kappa B$ through phosphorylation of IKK (inhibitor of the $\kappa B$ kinase) with two catalytic (IKK $\alpha$ 
and IKK $\beta$ ) and a regulatory subunit (IKK $\gamma$ ). In the canonical pathway, the activated IKK releases an NF- $\kappa B$ heterodimer (e.g., p50/RelA) from the inhibitory protein I $\kappa B$ for nuclear translocation. Different combinations of NF- $\mathrm{kB}$ dimers are complexed with various co-activators or transcription factors to regulate a variety of gene programs [34]. In the cohort study of type 2 diabetic nephropathy, NF- $\mathrm{KB}$ was specifically activated in renal tubular epithelial cells and significantly correlated with interstitial inflammation and proteinuria [35]. Furthermore, NF- $\mathrm{kB}$ also up-regulated in a number of renal diseases, including IgA nephropathy, immune-mediated inflammatory renal disease (crescentic glomerulonephritis, and lupus nephritis), minimal change disease, and membranous nephropathy [36]. NF-KB promotes inflammatory cytokines (e.g., IL-6, IL-1 $\beta$ ) production to exacerbate renal inflammation associated with acute kidney injury (AKI) and diabetic nephropathy, which is largely suppressed by JSH-23 (NF-KB inhibitor) [37-39]. Interestingly, injured kidney-derived IL-6 can initiate the production of pro-inflammatory FGF23 in bone, which further stimulates liver cells to synthesize IL-6 and FGF23 for promoting CKD via fibroblasts activation [40-42]. Indeed, increasing FGF-23 levels are independently associated with an increased risk for incident kidney replacement therapy [43].

\subsubsection{Toll-like Receptors}

Toll-like receptors (TLRs) are capable of detecting pathogens/damages for immune response. Pathogen-associated molecular patterns (PAMPs) in lipopolysaccharides (TLR4), peptidoglycans and lipoproteins (TLR1, 2, 6), viral RNA (TLR3), and unmethylated cytosine-guanosine dinucleotide (CPG)-DNA (TLR9) interact with specific TLRs to induce inflammatory cytokines and chemokines (TNF- $\alpha$, IL-1 $\beta$, IL-12, etc.) expression. The myeloid differentiation primary response protein 88 (MyD88) dependent pathway is the major TLRs signaling pathway [44,45]. TLRs also up-regulate co-stimulatory molecules in antigen-presenting dendritic cells (DC) [46]. In renal cells, TNF- $\alpha$ and IFN- $\gamma$ up-regulated TLR2, TLR4, and TLR6 in mesangial cells, but down-regulated them in macrophages [47]. TLR2 promotes crescentic glomerulonephritis [48], whereas TLR4 promotes inflammation associated with ischemic AKI in diabetic mice, which can be rescued by the TLR4 specific inhibitor CRX-526 [49,50]. Specifically, TLR4 expressed in dendritic cells and macrophages contributes to autoimmune disorder systemic lupus erythematosus via $\mathrm{T}_{\mathrm{H}} 1$ polarization, which can be suppressed by conditional knockout of TLR4 and MyD88 on macrophages and DCs [51-53].

\subsection{Fibrotic Pathway}

\subsubsection{TGF- $\beta 1 /$ Smads Signaling}

Transforming growth factor- $\beta 1$ (TGF- $\beta 1$ )/Smads signaling promotes renal fibrosis [54]. TGF- $\beta 1$ is secreted as a latent complex. Proteases cleavage releases TGF- $\beta 1$ to activate TGF- $\beta$ receptor type I (T $\beta R I)$ kinase for Smad2 and Smad3 phosphorylation and subsequent transcription $[8,55,56]$. Smad2/3 nuclear shuttling requires Smad4, which is essential for the Smad3 binding on the promoter region of collagen [57-59]. In addition, inhibitory Smad7 is degraded by the Smad ubiquitin regulatory factor (Smurf) to enhance TGF- $\beta 1 / \operatorname{Smad} 3$ signaling $[15,60]$. Among the Smads family, the pro-fibrotic role of Smad3 and anti-fibrotic role of Smad2 have been demonstrated by the loss-of-function studies in obstructive, diabetic, hypertensive, and acute toxic nephropathy in vivo [61]. Over the years, abundant evidence indicates the crucial role of Smads signaling dysregulation in fibrogenesis, extracellular matrix (ECM) synthesis, and myofibroblasts generation from macrophages, epithelial, and endothelial cells [55]. For example, global deletion and pharmacological inhibition of Smad3 protects against kidney fibrosis in UUO models [62,63]. Interestingly, conditional knockout of Tgfbr2 in proximal tubule (gGT-Cre) and tubular epithelial cells (Ksp-Cre) protect against AKI, whereas its loss in myeloid cells (LysM-Cre) promotes immunocytes $\left(\mathrm{CD}^{+} 5^{+}\right)$infiltration associated with elevated pro-inflammatory cytokines, indicating the anti-inflammatory role of TGF- $\beta 1$ [64-66]. Moreover, an activin A (ActA) antagonist, follistatin, blocks the TGF- $\beta 1$-induced $\alpha$-SMA and collagen I expression in renal fibroblasts and tubular cells, suggesting ActA as an autocrine factor for fibroblast activation in the development 
of kidney fibrosis $[67,68]$. To note, TGF- $\beta 1$ also induces ActA to suppress the circulating level of the Wnt inhibitor Dickkopf one (DKK1) to further enhance fibrotic responses via cross-talk with Wnt signaling [69].

\subsubsection{Wnt/ $\beta$-catenin Signaling}

The Wnt family comprises a group of secretory lipid-modified signaling glycoproteins, and they interact with the Frizzled (Fzd) family and their co-receptors to activate cytoplasmic Disheveled (Dsh/Dvl) proteins for promoting canonical ( $\beta$-catenin-dependent) or non-canonical ( $\beta$-catenin-independent) signaling [70,71]. The persistent activation of $\mathrm{Wnt} / \beta$-catenin signaling promotes chronic kidney disease and renal fibrosis. In an experimental CKD model, Wnt1 induces the prorenin receptor in kidney tubular epithelial cells to amplify the $\mathrm{Wnt} / \beta$-catenin mediated pro-fibrotic genes expression (TGF- $\beta$, fibronectin, collagen I, plasminogen activator inhibitor- 1 , matrix metalloproteinase 7) [72,73]. Furthermore, $\mathrm{Wnt} / \beta$-catenin signaling plays a crucial role in podocyte dysfunction, proteinuria, and glomerulosclerosis, particularly in diabetic nephropathy and focal segmental glomerulosclerosis [74,75]. Angiotensin II and high glucose activate $\mathrm{Wnt} / \beta$-catenin signaling in podocyte, triggering the ubiquitin-mediated degradation of Wilms' tumor 1 (WT1), a podocyte-specific transcription factor essential for their integrity and functions, resulting in albuminuria in mice [76-78]. Interestingly, condition knockout experiments showed that macrophages release Wnt7b to activate $\beta$-catenin signaling in tubular epithelial cells and dendritic cells for tissue regeneration and suppressing inflammation associated with Th1 differentiation, while the fibroblast-specific deletion of Wnt 4 suppresses renal fibrosis in UUO models [79-81], resulting in the anti-fibrotic effect of the CBP/ $\beta$-catenin inhibitor PRI-724 [82,83]. These studies suggest the anti-inflammatory and pro-fibrotic role of $\mathrm{Wnt} / \beta$-catenin signaling in a cell-type specific manner.

\subsubsection{MAP Kinases Signaling}

Mitogen-activated protein (MAP) kinases (ERK, p38, and JNK) can be activated by a wide range of stimulants such as growth factors, cytokines, and ligands for innate immune responses in a contextual manner. MAP kinases modulate TGF- $\beta 1$ production and activation to promote renal fibrosis [8,84-86]. ERK and JNK activate activator protein-1 (AP-1) to promote TGF- $\beta 1$-induced pro-fibrotic factors production, which contributes to the anti-fibrotic effect of the JNK inhibitor (CC-401) [87-89]. In mesangial cells, angiotensin II induces p38- and JNK-dependent thrombospondin-1 (TSP-1) expression for latent TGF- $\beta 1$ activation [90]. Moreover, MAP kinases can modulate Smad signaling via the canonical pathway [8]. TGF- $\beta 1$ also can induce ERK- and p38-dependent Smad3 activation, facilitating ECM synthesis, fibroblasts recruitment, and differentiation [91]. In addition, JNK promotes renal inflammation via the AP-1-mediated transcription of leukocyte adhesion molecules in endothelial cells and pro-inflammatory cytokines production in epithelial cells to facilitate leukocytes infiltration and recruitment, respectively [92].

\subsubsection{JAK/STAT Signaling}

The Janus kinase (JAK) family (JAK1, JAK2, JAK3, and TYK2) and signal transducer and activator of transcription (STAT) family (STAT1-STAT4, STAT5A, STAT5B, and STAT6) $[93,94]$ transduce signals for numerous growth factors and cytokines, including families of interferon (IFN), gp130, and $\gamma C$ in an isoform-specific manner [95]. Upon ligand binding, JAK phosphorylates the cytokine receptor via the tyrosine residues of the cytoplasmic domain, which in turn recruits and activates STAT for nuclear translocation to bind on their target genes. Among JAKs/STATs, the pro-fibrotic role of JAK2/STAT3 is observed in experimental models and clinical studies of renal dysfunction and fibrosis [96]. Berthier et al. found that JAK/STAT signaling up-regulated in mice models and patients with type 2 diabetic nephropathy [97]. Yokota et al. revealed that STAT3 activation (p-STAT3 (Tyr705)) mediates pro-inflammatory and fibrotic genes expression in Alport syndrome [98]. Bienaimé et al. further demonstrated that STAT3 in tubular cells promotes interstitial fibrosis and $\alpha$-smooth muscle 
actin ( $\alpha$-SMA) expression in 3/4 nephrectomy models [96]. On the contrary, Lan et al. showed the renoprotective role of STAT3 in acute aristolochic acid nephropathy [99], suggesting the contextual role of JAK/STAT signaling. Furthermore, conditional knockout models reveal the anti-inflammatory action of Stat3 in myeloid cells but pro-inflammatory role in T cells and epithelial cells [100-102]. Notably, the JAK1/2 inhibitor baricitinib effectively suppresses the progression of diabetic kidney disease, implicating the therapeutic implication of JAK/STAT signaling in renal fibrosis [103].

\section{Roles of Innate Immunity in CKD}

Renal injury eventually progresses to CKD under unresolved inflammation [104]. Upon kidney injury, damage-associated molecular patterns (DAMPs) trigger inflammatory responses, resulting in immunocytes infiltration predominantly to neutrophils, macrophages, and natural killer cells [105] (Figure 1). Together with resident dendritic cells, innate immune cells thus take corresponding roles in damage and repair on the site of injury. Recent studies reveal that renal cell death releases endogenous cytokines, chemokines, oxidative stress, and DAMPs, which largely promotes infiltration and activation of immune cells that result in CKD [106-109].

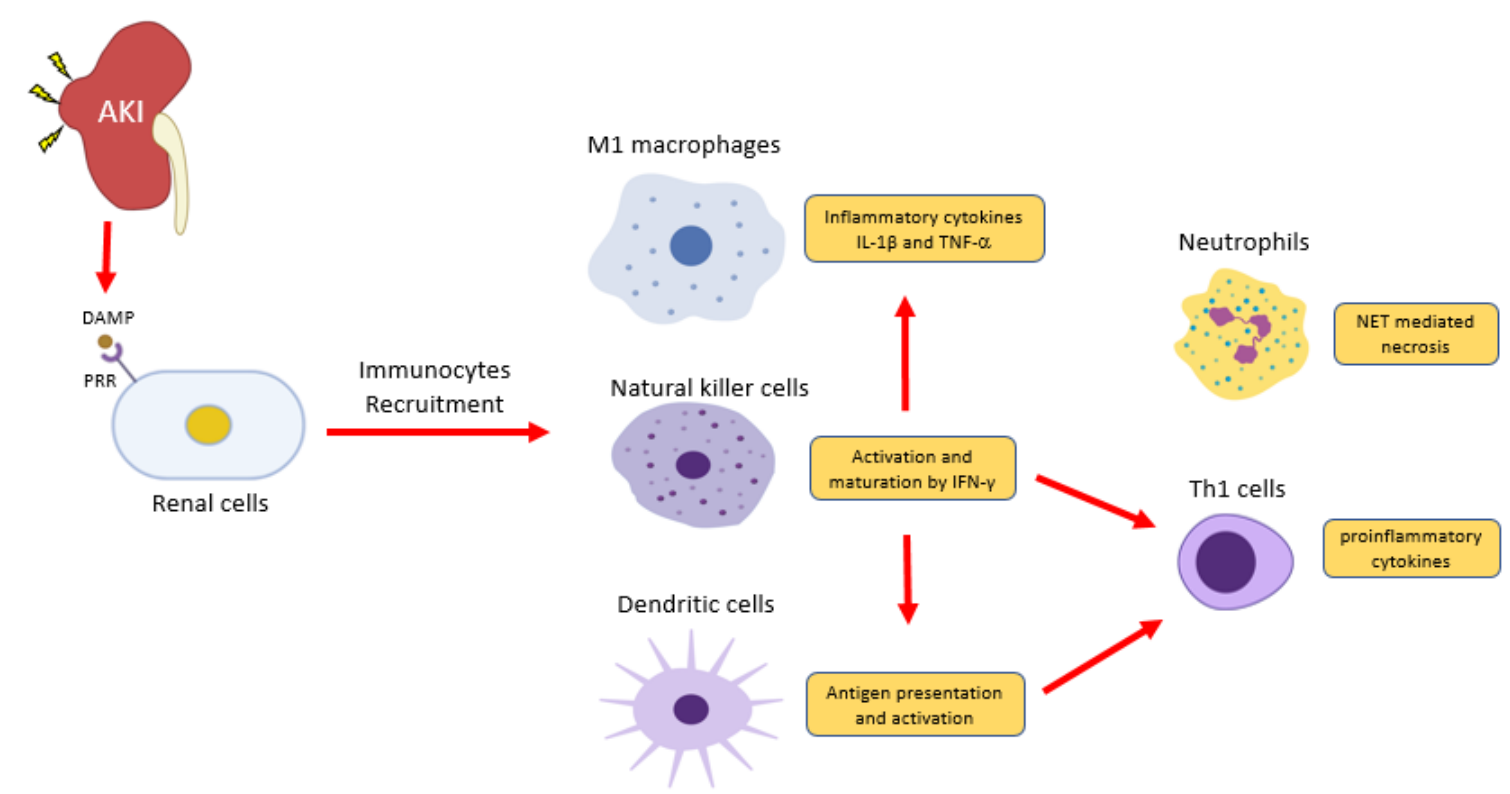

Figure 1. Inflammatory cells in acute kidney injury (AKI). Renal cells damage releases damage-associated molecular patterns (DAMPs) to induce inflammation via pattern recognition receptors (PRRs). Natural killer cells release IFN- $\gamma$ to induce classical activation of macrophage (M1)- producing pro-inflammatory cytokines IL-1 and TNF2 and induce dendritic cell maturation for pro-inflammatory Th1 differentiation. DAMPs also trigger the release of a neutrophils extracellular trap (NET) to further recruit inflammatory cells and induce renal cell death.

\subsection{Neutrophils}

Inflammation triggers the production of reactive oxygen species (ROS) and serine proteases of neutrophils upon adhesion to the injured site, which are believed to combat bacterial infection [106] and trigger the formation of neutrophil extracellular traps (NETs) [107]. NETs are found in acute tubular necrosis as a unique form of cell death, where intracellular membranes are degraded due to the histones and granule proteins attached on the ejecting chromatin [108]. Chromatin-released NETs also act as DAMPs to elicit inflammatory and cytotoxic effects, and Singh et al. reported that the histones released from NETs could enter and kill renal cells by nonspecific DNA and RNA binding. Besides, extracellular histones can ligate to the toll-like receptors -2 and -4 and nucleotide-binding domain (NOD)-like receptor protein 3 for inducing inflammasome [109]. Altogether, NETs generate an 
auto-amplification loop of inflammation to accelerate tubular necrosis, therefore causing irreversible damage to the nephrons [18].

\subsection{Dendritic Cells}

DCs are antigen-presenting cells. They are derived from bone marrow as an immature state as precursor DCs, then circulate into peripheral blood for foreign and pathogenic antigens detection [110]. Upon inflammatory stimuli at the injured site, endogenous DAMPs and PAMPs trigger the maturation of DCs for antigen presentation, cytokines, and co-stimulatory molecules expression. Interestingly, inflammatory stimuli transform dendritic cells to be a distinct subset called inflammatory DCs (infDCs), which activate $\mathrm{T}$ cells for promoting inflammation [111,112]. The infDCs secrete IL-1, TNF- $\alpha$, IL-12, and IL-23 to stimulate IL-17 production in $\mathrm{CD}^{+}$and $\mathrm{CD}^{+} \mathrm{T}$ cells in vivo [112]. Inhibition of Flt3, a ligand for cross-presentation between DCs and T cells, significantly reduces infiltration and proliferation of $\mathrm{CD}^{+}$and $\mathrm{CD}^{+} \mathrm{T}$ cells, therefore alleviating kidney inflammation in experimental adriamycin nephropathy models [22]. These findings suggest DCs could activate adaptive immunity and the autoimmune response for facilitating renal inflammation.

\subsection{Natural Killer Cells}

Natural killer (NK) cells are modulators of innate and adaptive immune responses. Their surface activating and inhibitory receptors are responsible for regulating NK cells' activities upon interactions to target cells, complementary and antagonist pathways that are initiated to trigger NK cells to secrete cytokines and chemokines to regulate neighboring immune cells $[113,114]$. Studies found that NK cells could promote Th1 polarization of CD4 ${ }^{+}$T cells and maturation of DCs through IFN- $\gamma$ [115]. In addition, the activated NK cells are capable of eliminating DCs that fail to complete their maturation [116]. It is believed that NK cells modulate differential immune responses depending on the cytokine environment. Recent in vitro studies found that exposure of NK cells to exogenous IL-12 would induce strong cytolytic activity against immature DCs; in contrast, IL-4-conditioned NK cells would generate DCs favoring T cell polarization or Th2 priming [117]. Thus, NK cells regulate DCs and T cells in the renal microenvironment.

\subsection{Macrophages}

Macrophages are highly plastic, and they contribute to every stage of CKD, from renal inflammation to fibrosis. In experimental CKD models, endogenous DAMPs and PAMPs induce M1 pro-inflammatory macrophages [118-121], therefore producing inflammatory cytokines IL-1 $\beta$ and TNF $\alpha$ to promote renal inflammation $[25,26,122]$. Nevertheless, studies also reported that macrophage infiltration correlates with active fibrotic lesions, supported by the significant reduction in renal fibrosis in IRI and UUO models under macrophage depletion [123,124]. M1 macrophages induce chronic renal inflammation, resulting in collagen and extracellular matrix deposition [125]. During CKD progression, M1 is gradually replaced by the reparative M2 phenotype [126]. The M1/M2 transition is evident and characterized by a time-dependent exchange of M1/M2 markers and the existence of their intermediate population, detected by single-cell sequencing analysis in AKI, glomerular disease, and UUO models [127-129]. Clinical studies of diabetic nephropathy [130] and kidney transplantation [131] showed that M2 macrophages localize at the fibrotic areas and actively produce pro-fibrotic molecules IL-1, PDGF, MMP-2/9/12, and galectin 3 [27,28]. Moreover, bone marrow-derived macrophages (BMDM) could further differentiate into $\alpha-\mathrm{SMA}^{+}$myofibroblasts locally in injured kidney under unresolved inflammation for promoting renal fibrosis $[31,131]$. These studies demonstrate the pro-fibrotic role of M2 macrophages in renal fibrosis.

\section{Novel Pathogenic Mechanism: Macrophage-Myofibroblast Transition}

Myofibroblasts are activated fibroblasts featured with an $\alpha$-SMA expression and pathogenic collagen production during tissue fibrosis [132]. Previous studies identified that BMDM could further 
differentiate into $\alpha$-SMA ${ }^{+}$myofibroblasts via a novel mechanism, namely macrophage-myofibroblast transition (MMT) [30,31] (Figure 2). MMT cells co-expressing macrophage $\left(\mathrm{CD}^{+} 8^{+}\right)$and myofibroblast $\left(\alpha-\mathrm{SMA}^{+}\right)$markers were detected and positively correlated with the abundance of myofibroblasts in active chronic renal allograft injury [30]. The role of MMT in tissue scarring was demonstrated in vivo, and macrophage-lineage myofibroblasts and their intermediate cells $\left(\mathrm{F} 4 / 80^{+} \alpha-\mathrm{SMA}^{+}\right)$exist in fibrotic kidney of Crim 1 hypomorphic mice, UUO, and chronic renal allograft rejection mouse models [133]. These studies provide experimental evidence for the pathogenic role of MMT in renal fibrosis.

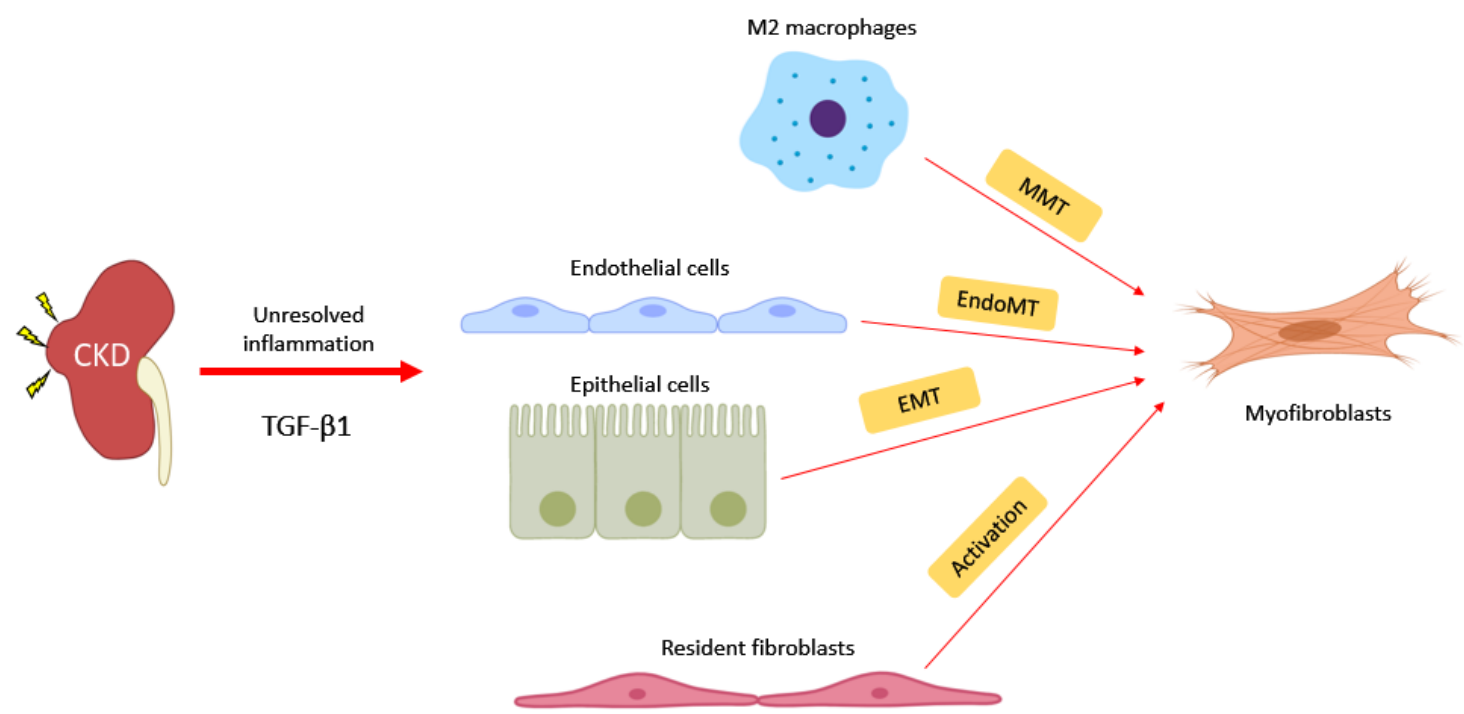

Figure 2. Macrophages promote chronic kidney disease (CKD) progression from AKI to fibrosis. During unresolved inflammation, TGF- $\beta 1$ further differentiates M2 macrophages into myofibroblasts. Therefore, TGF- $\beta 1$ triggers myofibroblasts formation via the macrophage-myofibroblast transition (MMT), endothelial-mesenchymal transition (EndoMT), epithelial-mesenchymal transition (EMT), and fibroblast activation in the fibrotic kidney.

MMT is driven by the TGF $\beta 1 / \mathrm{Smad} 3$ signaling pathways in fibrotic kidney $[8,55]$. A deficiency of Smad3 protects against myofibroblast formation and renal fibrosis in various experimental mouse kidney injury models $[134,135]$. Src is the upstream of Smad3, regulating fibroblast proliferation and renal fibrosis [136]. Unexpectedly, we recently revealed that Src can also serve as the direct target gene of TGF $\beta 1 / \mathrm{Smad} 3$ signaling for promoting MMT via a regulatory gene network in UUO-injured kidney [137]. Thus, MMT may represent a novel therapeutic target for blocking CKD development.

\section{The Perspective of Immunosuppressive for CKD}

\subsection{Clinical Ready Immunotherapy for CKD}

Indeed, a number of immunosuppressive agents are already prescribed for immune-mediated kidney diseases including AKI, CKD, and GvHD. The use of immunosuppressors in CKD is still under debate, only patients with massive proteinuria will receive these treatments to balance the benefit and risk of immunosuppression. In this section, we will summarize the potential therapeutic strategies according to the immune cell targets.

\subsection{1. $T$ cell-targeted Therapy}

$\mathrm{T}$ cell targeted therapy works in three ways by targeting 1 ) the interaction between the $\mathrm{T}$ cell receptor complex and antigen-presenting cells (APC); 2) co-stimulatory signals on T cell/APC; and 3) cytokine driven activation and proliferation [138]. For example, calcineurin inhibitors (CNIs) are commonly used in nephropathy treatment, which prevents the nuclear translocation of nuclear factor of activated T cells (NFAT). However, dose-dependent renal toxicity, dysfunction, and failure were 
observed in nephropathy and post-renal transplantation after prolonged treatment with the CNIs cyclosporin and tacrolimus and an investigational agent voclosporin $[139,140]$. New extended-release formulations and CNIs may overcome these side effects [141,142]. T cells express CTLA4 (cytotoxic T lymphocyte-associated protein 4) to competitively inhibit the co-stimulatory signals CD80/CD86 on APC [143]. Recombinant CTLA4-Ig has been developed and approved for rheumatoid arthritis and focal segmental glomerulosclerosis (FSGS) with $\mathrm{CD} 80^{+}$podocytes.

\subsubsection{B cell-targeted Therapy}

B cell-targeted therapy suppresses the maturation and differentiation of $\mathrm{B}$ cells into antibody-producing plasma cells by inhibiting CD20, CD22, and B cell activating factor (BAFF) to alter the course of autoimmune and alloimmune diseases' progression [138]. Rituximab targets CD20 to prevent $\mathrm{B}$ cell proliferation and induce apoptosis via both complement-dependent and -independent mechanisms. Recently, rituximab is widely used in idiopathic membranous nephropathy (IMN), FSGS, and lupus nephritis with anecdotal success [144]. Belimumab improves the renal condition of systemic lupus erythematosus by suppressing B cell survival and differentiation via targeting the soluble BAFF [145]. Bortezomib inhibits the antibody production of mature plasma cells, which is effective in renal function improvement [146]. However, direct evidence of T cell- or B cell-targeted agents in renal fibrosis is still lacking.

\subsubsection{Mesenchymal Stem Cells (MSCs) Therapy}

Mesenchymal stem cells (MSCs) therapy is a new therapeutic strategy for end-stage renal disease (ESRD) [147]. MSCs are pluripotent stem cells capable of differentiating into various tissue types for diverse biological functions including immune regulation. Several studies explored the feasibility of MSCs for renal fibrosis therapy. MSCs transfusion effectively suppressed renal fibrosis in experimental models by inhibiting both the pro-inflammatory and pro-fibrotic signaling pathways, including TGF- $\beta 1 /$ Smad3, TLR4/NK-kB, and ERK [147-149]. MSCs-based therapy facilitates tissue repair in experimental models and patients with AKI [150], and diminishes kidney fibrosis in obstructive nephropathy when combined with a low dose of tacrolimus [151]. More importantly, MSCs-based therapy significantly decreases the rate of solute transport across the peritoneal membrane in peritoneal dialysis patients, resulting in better clinical outcomes [152]. MSCs therapies have demonstrated their renal protective effects in mice models and clinical trials, and there are on-going clinical trials which should further validate the effectiveness of MSCs therapy in ESRD.

\subsubsection{Chimeric Antigen Receptor T (CAR T) Cells Therapy}

The chimeric antigen receptor (CAR) $\mathrm{T}$ cell is an engineered cytotoxic $\mathrm{T}$ cell activated by the direct recognition of an antigen without a major histocompatibility complex (MHC). T cells are obtained from patients by leukapheresis, then expanded and transduced with viral vectors encoding the fusion protein CAR for recognizing the targeted antigen. Finally, these CAR T cells are infused back to the patients $[153,154]$. CAR T cell therapy is usually accompanied by immune effector cell-associated neurological syndrome (ICANS) and cytokine release syndrome (CRS), while direct renal toxicity is not acknowledged. In a retrospective review, Gupta et al. found that CAR T therapy restored the kidney function of 46 patients with non-Hodgkin lymphoma to the baseline within 30 days and helped to recover from AKI [155]. Kitching et al. suggested that CAR T cells could be applied to autoimmune diseases, including kidney transplantation, by loading CAR into cytotoxic $\mathrm{T}$ cells to eliminate autoreactive $\mathrm{B}$ cells and into regulatory $\mathrm{T}$ cells to suppress the autoimmune response locally [156]. 


\subsubsection{Inflammatory Reflex Targeted Therapy}

In AKI, the central nervous system (CNS) has been reported to regulate the immune response via inflammatory reflex. Upon injury, danger stimuli including DAMPs activate pattern recognition receptors (PRRs) on the local afferent vagus nerve to generate a signal transmitted through the CNS and efferent vagus nerve to the splenic nerve that stimulates the release of noradrenaline in the spleen $[157,158]$. Noradrenaline activates choline acetyltransferase positive $\mathrm{T}$ cells $\left(\mathrm{ChAT}^{+}\right)$via the $\beta 2$-adrenergic receptor, leading to the subsequent release of acetylcholine, which binds to the $\alpha 7$ nicotinic acetylcholine receptor $(\alpha 7 \mathrm{nAChR})$ on macrophages to suppress pro-inflammatory cytokines production [159]. Therapeutic strategies mimicking the efferent arm of the inflammatory reflex by applying pulsed ultrasound to the spleen or $\alpha 7 \mathrm{nAChR}$ agonists successfully protected kidney against AKI in experimental models, suggesting neuro-immune control is a potential target to suppress renal inflammation $[160,161]$.

\subsection{Effect of Immunotherapy in Experimental CKD Models}

Leukocyte infiltration plays a pivotal role in the pathogenesis of renal fibrosis. Upon injury, infiltrated leukocytes secret pro-inflammatory cytokines to amplify the inflammatory responses, the unresolved inflammation eventually resulting in renal fibrosis as well as the loss of kidney functions. Therefore, therapies preventing leukocytes infiltration have been widely studied. A study reported that circulating $\mathrm{T}$ cell clones may directly activate renal epithelial cells or promote a T/B cell population with autoimmune reactive properties against kidney cells [162]. Activating the AT1 receptor on $\mathrm{T}$ cells effectively suppresses renal fibrogenesis by inhibiting Th1 differentiation and renal accumulation of pro-fibrotic macrophages [163]. Furthermore, macrophage infiltration and collagen deposition were attenuated by genetic and anti-CD20-mediated B cell depletion in mice with obstructive nephropathy [164]. Macrophages are versatile, which participated in the pathogenesis of renal diseases as well as vital physiological functions (e.g., tissue repair, immune regulation, and defense against pathogen). To minimize the side effects, specific strategies were developed to suppress pathogenic macrophage infiltration, polarization, and myofibroblast transition via chemokines (CCL2, CCL5, CXCL16, and CCL21) and their receptors, Src, JAK-STAT, and TGF $\beta 1 / S m a d 3$ signaling inhibition, respectively, to attenuate the progression of renal fibrosis. These macrophage-targeting strategies may be translated by further clinical investigation [9].

\section{Conclusions}

Patients who recover from acute kidney injury are likely to progress into chronic kidney disease, and eventually lead to end-stage renal diseases. Innate immunity is the first line of inflammatory cells infiltrated into the injured kidney, performing diverse functions, from amplifying the inflammatory response to renal repair. However, they also largely contribute to the development of renal fibrosis during the transition of AKI into CKD under unresolved renal inflammation. Therefore, a better understanding of the underlying mechanism may uncover effective therapeutic strategies for blocking the progression of CKD.

Author Contributions: P.C.-T.T., Y.-Y.Z., W.W.-Y.L., M.K.-K.C., and J.Y.-F.C. responsible for literature research and writing. H.-Y.L., K.-F.T., and W.K. reviewed the manuscript and made significant revisions on the drafts. P.M.-K.T. supervised and finalized of this work. All authors have read and agreed to the published version of the manuscript.

Funding: This study was supported by Research Grants Council of Hong Kong (RGC 14106518, 14111019, 14121816, 14163317, 14117418, 14104019, C7018-16G); Innovation and Technology Fund of Hong Kong (ITS/068/18, $\mathrm{PiH} / 009 / 19, \mathrm{PiH} / 010 / 19, \mathrm{PiH} / 394 / 19$, InP/008/19, InP/009/19, InP/159/19); Faculty Innovation Award and Direct Grant for Research of The Chinese University of Hong Kong CUHK $(4620528,4054386,4054440)$.

Conflicts of Interest: The authors declare no conflict of interest. 


\section{Abbreviations}

\begin{tabular}{|c|c|}
\hline ActA & Activin A \\
\hline$\alpha 7 \mathrm{nAChR}$ & $\alpha 7$ Nicotinic Acetylcholine Receptor \\
\hline AKI & Acute Kidney Injury \\
\hline $\mathrm{AP}-1$ & Activator Protein-1 \\
\hline $\mathrm{APC}$ & Antigen-Presenting Cell \\
\hline$\alpha-S M A$ & Alpha-Smooth Muscle Actin \\
\hline BAFF & B-Cell Activating Factor \\
\hline CAR-T & Chimeric Antigen Receptor T Cells \\
\hline CD- & Cluster of Differentiation- \\
\hline ChAT+ & Choline Acetyltransferase Positive T Cells \\
\hline CKD & Chronic Kidney Disease \\
\hline CNIs & Calcineurin Inhibitors \\
\hline CTLA4 & Cytotoxic T-Lymphocyte-Associated Protein 4 \\
\hline DAMPs & Damage-Associated Molecular Patterns \\
\hline $\mathrm{DC}$ & Dendritic Cell \\
\hline DKK1 & Dickkopf One \\
\hline EMT & Epithelial-Mesenchymal Transition \\
\hline EndoMT & Endothelial-Mesenchymal Transition \\
\hline ERK & Extracellular-Signal-Regulated Kinase \\
\hline ESRD & End-Stage Renal Disease \\
\hline FGF-23 & Fibroblast Growth Factor 23 \\
\hline FSGS & Focal Segmental Glomerulosclerosis \\
\hline gGT1-Cre & Gamma-Glutamyltransferase 1, Promoter. Cre \\
\hline GVHD & Graft Versus Host Disease \\
\hline IFN- & Interferon- \\
\hline IKK & Ikb Kinase \\
\hline IL- & Interleukin- \\
\hline IMN & Idiopathic Membranous Nephropathy \\
\hline IRI & Ischemia/Reperfusion Injury \\
\hline JAK & Janus Kinase \\
\hline JNK & C-Jun N-Terminal Kinase \\
\hline Ksp-Cre & Cadherin 16 Promoter. Cre \\
\hline LAP & Latency-Associated Peptide \\
\hline LPS & Lipopolysaccharides \\
\hline LTBP & Latent TGF- $\beta$ Binding Proteins \\
\hline MAPK & Mitogen-Activated Protein Kinases \\
\hline MCP-1 & Monocyte Chemoattractant Protein-1 \\
\hline MHC & Major Histocompatibility Complex \\
\hline MMP- & Matrix Metallopeptidase- \\
\hline MMT & Macrophage-To-Myofibroblast Transition \\
\hline MSCs & Mesenchymal Stem Cells \\
\hline MYD88 & Myeloid Differentiation Factor 88 \\
\hline NETs & Neutrophil Extracellular Traps \\
\hline NFAT & Nuclear Factor of Activated T-Cells \\
\hline NF-kB & Nuclear Factor Kappa-Light-Chain-Enhancer of Activated B Cells \\
\hline NK & Natural Killer Cell \\
\hline PAMPs & Pathogen-Associated Molecular Patterns \\
\hline PDGF & Platelet-Derived Growth Factor \\
\hline ROS & Reactive Oxygen Species \\
\hline SMADs & Mothers Against Decapentaplegic Homologs \\
\hline SRC & Proto-Oncogene Tyrosine-Protein Kinase Src \\
\hline
\end{tabular}




$\begin{array}{ll}\text { STAT } & \text { Signal Transducer and Activator Of Transcription } \\ \text { TCR } & \text { T-Cell Receptor } \\ \text { TGF- } \beta & \text { Transforming Growth Factor-Beta } \\ \text { TGFBR2 } & \text { Transforming Growth Factor Beta Receptor } 2 \\ \text { Th1/2 } & \text { T Helper Type 1/2 } \\ \text { TLRs } & \text { Toll-Like Receptors } \\ \text { TNF- } & \text { Tumor Necrosis Factor } \\ \text { TSP-1 } & \text { Thrombospondin-1 } \\ \text { TBRI } & \text { TGF- } \beta \text { Receptor Type I } \\ \text { UUO } & \text { Unilateral Ureter Obstruction } \\ \text { WNT } & \text { Wingless-Type MMTV Integration Site Family }\end{array}$

\section{References}

1. Lv, J.C.; Zhang, L.X. Prevalence and Disease Burden of Chronic Kidney Disease. Adv. Exp. Med. Biol. 2019, 1165, 3-15. [PubMed]

2. Humphreys, B.D. Mechanisms of Renal Fibrosis. Annu. Rev. Physiol. 2018, 80, 309-326. [CrossRef] [PubMed]

3. Lopez-Novoa, J.M.; Martinez-Salgado, C.; Rodriguez-Pena, A.B.; Lopez-Hernandez, F.J. Common pathophysiological mechanisms of chronic kidney disease: Therapeutic perspectives. Pharmacol. Ther. 2010, 128, 61-81. [CrossRef]

4. Nogueira, A.; Pires, M.J.; Oliveira, P.A. Pathophysiological Mechanisms of Renal Fibrosis: A Review of Animal Models and Therapeutic Strategies. Vivo 2017, 31, 1-22. [CrossRef]

5. El Nahas, A.M. Glomerulosclerosis: Intrinsic and extrinsic pathways. Nephrol. Dial. Transplant. 1996, 11, 773-777. [CrossRef]

6. Tang, P.M.; Zhang, Y.Y.; Lan, H.Y. LncRNAs in TGF- $\beta$-Driven Tissue Fibrosis. Noncoding RNA 2018, 4, 26. [CrossRef]

7. Lan, H.Y. Tubular epithelial-myofibroblast transdifferentiation mechanisms in proximal tubule cells. Curr. Opin. Nephrol. Hypertens. 2003, 12, 25-29. [CrossRef]

8. Meng, X.M.; Nikolic-Paterson, D.J.; Lan, H.Y. TGF-beta: The master regulator of fibrosis. Nat. Rev. Nephrol. 2016, 12, 325-338. [CrossRef]

9. Tang, P.M.; Nikolic-Paterson, D.J.; Lan, H.Y. Macrophages: Versatile players in renal inflammation and fibrosis. Nat. Rev. Nephrol. 2019, 15, 144-158. [CrossRef]

10. Qi, R.; Yang, C. Renal tubular epithelial cells: The neglected mediator of tubulointerstitial fibrosis after injury. Cell Death Dis. 2018, 9, 1126. [CrossRef]

11. Qian, Y.; Feldman, E.; Pennathur, S.; Kretzler, M.; Brosius, F.C., III. From fibrosis to sclerosis: Mechanisms of glomerulosclerosis in diabetic nephropathy. Diabetes 2008, 57, 1439-1445. [CrossRef] [PubMed]

12. Meng, X.M.; Nikolic-Paterson, D.J.; Lan, H.Y. Inflammatory processes in renal fibrosis. Nat. Rev. Nephrol. 2014, 10, 493-503. [CrossRef] [PubMed]

13. Hickey, F.B.; Martin, F. Role of the Immune System in Diabetic Kidney Disease. Curr. Diab. Rep. 2018, 18, 20. [CrossRef]

14. Tecklenborg, J.; Clayton, D.; Siebert, S.; Coley, S.M. The role of the immune system in kidney disease. Clin. Exp. Immunol. 2018, 192, 142-150. [CrossRef]

15. Kurts, C.; Panzer, U.; Anders, H.J.; Rees, A.J. The immune system and kidney disease: Basic concepts and clinical implications. Nat. Rev. Immunol. 2013, 13, 738-753. [CrossRef]

16. Wang, Y.H.; Zhang, Y.G. Kidney and innate immunity. Immunol. Lett. 2017, 183, 73-78. [CrossRef]

17. Hayden, M.S.; Ghosh, S. Shared principles in NF-kappaB signaling. Cell 2008, 132, 344-362. [CrossRef] [PubMed]

18. Andrade-Oliveira, V.; Foresto-Neto, O.; Watanabe, I.K.M.; Zatz, R.; Camara, N.O.S. Inflammation in Renal Diseases: New and Old Players. Front. Pharmacol. 2019, 10, 1192. [CrossRef] [PubMed]

19. Rangan, G.; Wang, Y.; Harris, D. NF-kappaB signalling in chronic kidney disease. Front Biosci. (Landmark Ed.) 2009, 14, 3496-3522. [CrossRef] 
20. Mezzano, S.; Aros, C.; Droguett, A.; Burgos, M.E.; Ardiles, L.; Flores, C.; Schneider, H.; Ruiz-Ortega, M.; Egido, J. NF-kappaB activation and overexpression of regulated genes in human diabetic nephropathy. Nephrol. Dial. Transplant. 2004, 19, 2505-2512. [CrossRef]

21. Sanz, A.B.; Sanchez-Nino, M.D.; Ramos, A.M.; Moreno, J.A.; Santamaria, B.; Ruiz-Ortega, M.; Egido, J.; Ortiz, A. NF-kappaB in renal inflammation. J. Am. Soc. Nephrol. 2010, 21, 1254-1262. [CrossRef] [PubMed]

22. Liu, Z.; Huang, X.R.; Chen, H.Y.; Penninger, J.M.; Lan, H.Y. Loss of angiotensin-converting enzyme 2 enhances TGF-beta/Smad-mediated renal fibrosis and NF-kappaB-driven renal inflammation in a mouse model of obstructive nephropathy. Lab. Investig. 2012, 92, 650-661. [CrossRef] [PubMed]

23. Ozkok, A.; Ravichandran, K.; Wang, Q.; Ljubanovic, D.; Edelstein, C.L. NF-kappaB transcriptional inhibition ameliorates cisplatin-induced acute kidney injury (AKI). Toxicol. Lett. 2016, 240, 105-113. [CrossRef]

24. Zhu, L.; Han, J.; Yuan, R.; Xue, L.; Pang, W. Berberine ameliorates diabetic nephropathy by inhibiting TLR4/NF-kappaB pathway. Biol. Res. 2018, 51, 9. [CrossRef]

25. Czaya, B.; Faul, C. FGF23 and inflammation-a vicious coalition in CKD. Kidney Int. 2019, 96, 813-815. [CrossRef]

26. Cianciolo, G.; Galassi, A.; Capelli, I.; Schillaci, R.; La Manna, G.; Cozzolino, M. Klotho-FGF23, Cardiovascular Disease, and Vascular Calcification: Black or White? Curr. Vasc. Pharmacol. 2018, 16, 143-156. [CrossRef]

27. Mattinzoli, D.; Ikehata, M.; Tsugawa, K.; Alfieri, C.M.; Dongiovanni, P.; Trombetta, E.; Valenti, L.; Puliti, A.; Lazzari, L.; Messa, P. FGF23 and Fetuin-A Interaction in the Liver and in the Circulation. Int. J. Biol. Sci. 2018, 14, 586-598. [CrossRef]

28. Mehta, R.; Cai, X.; Lee, J.; Xie, D.; Wang, X.; Scialla, J.; Anderson, A.H.; Taliercio, J.; Dobre, M.; Chen, J.; et al. Serial Fibroblast Growth Factor 23 Measurements and Risk of Requirement for Kidney Replacement Therapy: The CRIC (Chronic Renal Insufficiency Cohort) Study. Am. J. Kidney Dis. 2019, 75, 908-918. [CrossRef]

29. Anders, H.J.; Banas, B.; Schlondorff, D. Signaling danger: Toll-like receptors and their potential roles in kidney disease. J. Am. Soc. Nephrol. 2004, 15, 854-867. [CrossRef]

30. Gluba, A.; Banach, M.; Hannam, S.; Mikhailidis, D.P.; Sakowicz, A.; Rysz, J. The role of Toll-like receptors in renal diseases. Nat. Rev. Nephrol. 2010, 6, 224-235. [CrossRef]

31. Kawai, T.; Akira, S. The role of pattern-recognition receptors in innate immunity: Update on Toll-like receptors. Nat. Immunol. 2010, 11, 373-384. [CrossRef]

32. Anders, H.J.; Schlondorff, D. Toll-like receptors: Emerging concepts in kidney disease. Curr. Opin. Nephrol. Hypertens. 2007, 16, 177-183. [CrossRef]

33. O'ullivan, K.M.; Ford, S.L.; Longano, A.; Kitching, A.R.; Holdsworth, S.R. Intrarenal Toll-like receptor 4 and Toll-like receptor 2 expression correlates with injury in antineutrophil cytoplasmic antibody-associated vasculitis. Am. J. Physiol. Renal. Physiol. 2018, 315, F1283-F1294. [CrossRef]

34. Gao, G.; Zhang, B.; Ramesh, G.; Betterly, D.; Tadagavadi, R.K.; Wang, W.; Reeves, W.B. TNF-alpha mediates increased susceptibility to ischemic AKI in diabetes. Am. J. Physiol. Renal. Physiol. 2013, 304, F515-F521. [CrossRef]

35. Lin, M.; Yiu, W.H.; Li, R.X.; Wu, H.J.; Wong, D.W.; Chan, L.Y.; Leung, J.C.; Lai, K.N.; Tang, S.C. The TLR4 antagonist CRX-526 protects against advanced diabetic nephropathy. Kidney Int. 2013, 83, 887-900. [CrossRef]

36. Chen, J.Q.; Szodoray, P.; Zeher, M. Toll-Like Receptor Pathways in Autoimmune Diseases. Clin. Rev. Allergy. Immunol. 2016, 50, 1-17. [CrossRef]

37. Hou, B.; Reizis, B.; DeFranco, A.L. Toll-like receptors activate innate and adaptive immunity by using dendritic cell-intrinsic and -extrinsic mechanisms. Immunity. 2008, 29, 272-282. [CrossRef]

38. Zettel, K.; Korff, S.; Zamora, R.; Morelli, A.E.; Darwiche, S.; Loughran, P.A.; Elson, G.; Shang, L.; Salgado-Pires, S.; Scott, M.J.; et al. Toll-Like Receptor 4 on both Myeloid Cells and Dendritic Cells Is Required for Systemic Inflammation and Organ Damage after Hemorrhagic Shock with Tissue Trauma in Mice. Front. Immunol. 2017, 8, 1672. [CrossRef]

39. Lan, H.Y.; Chung, A.C. TGF-beta/Smad signaling in kidney disease. Semin. Nephrol. 2012, 32, $236-243$. [CrossRef] [PubMed]

40. Tang, P.M.; Zhang, Y.Y.; Mak, T.S.; Tang, P.C.; Huang, X.R.; Lan, H.Y. Transforming growth factor-beta signalling in renal fibrosis: From Smads to non-coding RNAs. J. Physiol. 2018, 596, 3493-3503. [CrossRef] [PubMed] 
41. Lan, H.Y. Diverse roles of TGF-beta/Smads in renal fibrosis and inflammation. Int. J. Biol. Sci. 2011, 7, 1056-1067. [CrossRef] [PubMed]

42. Duan, W.J.; Yu, X.; Huang, X.R.; Yu, J.W.; Lan, H.Y. Opposing roles for Smad2 and Smad3 in peritoneal fibrosis in vivo and in vitro. Am. J. Pathol. 2014, 184, 2275-2284. [CrossRef] [PubMed]

43. Meng, X.M.; Huang, X.R.; Chung, A.C.; Qin, W.; Shao, X.; Igarashi, P.; Ju, W.; Bottinger, E.P.; Lan, H.Y. Smad2 protects against TGF-beta/Smad3-mediated renal fibrosis. J. Am. Soc. Nephrol. 2010, 21, 1477-1487. [CrossRef]

44. Meng, X.M.; Huang, X.R.; Xiao, J.; Chung, A.C.; Qin, W.; Chen, H.Y.; Lan, H.Y. Disruption of Smad4 impairs TGF-beta/Smad3 and Smad7 transcriptional regulation during renal inflammation and fibrosis in vivo and in vitro. Kidney Int. 2012, 81, 266-279. [CrossRef]

45. Kavsak, P.; Rasmussen, R.K.; Causing, C.G.; Bonni, S.; Zhu, H.; Thomsen, G.H.; Wrana, J.L. Smad7 binds to Smurf2 to form an E3 ubiquitin ligase that targets the TGF beta receptor for degradation. Mol. Cell 2000, 6, 1365-1375. [CrossRef]

46. Zhang, Y.; Meng, X.M.; Huang, X.R.; Wang, X.J.; Yang, L.; Lan, H.Y. Transforming growth factor-beta1 mediates psoriasis-like lesions via a Smad3-dependent mechanism in mice. Clin. Exp. Pharmacol. Physiol. 2014, 41, 921-932. [CrossRef]

47. Feng, M.; Tang, P.M.; Huang, X.R.; Sun, S.F.; You, Y.K.; Xiao, J.; Lv, L.L.; Xu, A.P.; Lan, H.Y. TGF-beta Mediates Renal Fibrosis via the Smad3-Erbb4-IR Long Noncoding RNA Axis. Mol. Ther. 2018, 26, 148-161. [CrossRef]

48. Ji, X.; Wang, H.; Wu, Z.; Zhong, X.; Zhu, M.; Zhang, Y.; Tan, R.; Liu, Y.; Li, J.; Wang, L. Specific Inhibitor of Smad3 (SIS3) Attenuates Fibrosis, Apoptosis, and Inflammation in Unilateral Ureteral Obstruction Kidneys by Inhibition of Transforming Growth Factor beta (TGF-beta)/Smad3 Signaling. Med. Sci. Monit. 2018, 24, 1633-1641. [CrossRef]

49. Yang, Q.; Ren, G.L.; Wei, B.; Jin, J.; Huang, X.R.; Shao, W.; Li, J.; Meng, X.M.; Lan, H.Y. Conditional knockout of TGF-betaRII /Smad2 signals protects against acute renal injury by alleviating cell necroptosis, apoptosis and inflammation. Theranostics 2019, 9, 8277-8293. [CrossRef]

50. Gewin, L.; Vadivelu, S.; Neelisetty, S.; Srichai, M.B.; Paueksakon, P.; Pozzi, A.; Harris, R.C.; Zent, R. Deleting the TGF-beta receptor attenuates acute proximal tubule injury. J. Am. Soc. Nephrol. 2012, 23, 2001-2011. [CrossRef]

51. Hollander, M.C.; Latour, L.L.; Yang, D.; Ishii, H.; Xiao, Z.; Min, Y.; Ray-Choudhury, A.; Munasinghe, J.; Merchant, A.S.; Lin, P.C.; et al. Attenuation of Myeloid-Specific TGFbeta Signaling Induces Inflammatory Cerebrovascular Disease and Stroke. Circ. Res. 2017, 121, 1360-1369. [CrossRef] [PubMed]

52. Wada, W.; Kuwano, H.; Hasegawa, Y.; Kojima, I. The dependence of transforming growth factor-beta-induced collagen production on autocrine factor activin A in hepatic stellate cells. Endocrinology 2004, 145, 2753-2759. [CrossRef] [PubMed]

53. Yamashita, S.; Maeshima, A.; Kojima, I.; Nojima, Y. Activin A is a potent activator of renal interstitial fibroblasts. J. Am. Soc. Nephrol. 2004, 15, 91-101. [CrossRef]

54. Mehta, N.; Krepinsky, J.C. The emerging role of activins in renal disease. Curr. Opin. Nephrol. Hypertens. 2020, 29, 136-144. [CrossRef]

55. Wang, Y.; Zhou, C.J.; Liu, Y. Wnt Signaling in Kidney Development and Disease. Prog. Mol. Biol. Transl. Sci. 2018, 153, 181-207.

56. Clevers, H.; Nusse, R. Wnt/beta-catenin signaling and disease. Cell 2012, 149, 1192-1205. [CrossRef]

57. Li, Z.; Zhou, L.; Wang, Y.; Miao, J.; Hong, X.; Hou, F.F.; Liu, Y. (Pro)renin Receptor Is an Amplifier of Wnt/beta-Catenin Signaling in Kidney Injury and Fibrosis. J. Am. Soc. Nephrol. 2017, 28, 2393-2408. [CrossRef]

58. Cruciat, C.M.; Ohkawara, B.; Acebron, S.P.; Karaulanov, E.; Reinhard, C.; Ingelfinger, D.; Boutros, M.; Niehrs, C. Requirement of prorenin receptor and vacuolar H+-ATPase-mediated acidification for Wnt signaling. Science 2010, 327, 459-463. [CrossRef]

59. Zhou, L.; Liu, Y. Wnt/beta-catenin signalling and podocyte dysfunction in proteinuric kidney disease. Nat. Rev. Nephrol. 2015, 11, 535-545. [CrossRef]

60. Naves, M.A.; Requiao-Moura, L.R.; Soares, M.F.; Silva-Junior, J.A.; Mastroianni-Kirsztajn, G.; Teixeira, V.P. Podocyte Wnt/ss-catenin pathway is activated by integrin-linked kinase in clinical and experimental focal segmental glomerulosclerosis. J. Nephrol. 2012, 25, 401-409. [CrossRef] 
61. Zhou, L.; Li, Y.; He, W.; Zhou, D.; Tan, R.J.; Nie, J.; Hou, F.F.; Liu, Y. Mutual antagonism of Wilms' tumor 1 and beta-catenin dictates podocyte health and disease. J. Am. Soc. Nephrol. 2015, 26, 677-691. [CrossRef] [PubMed]

62. Cuevas, C.A.; Gonzalez, A.A.; Inestrosa, N.C.; Vio, C.P.; Prieto, M.C. Angiotensin II increases fibronectin and collagen I through the beta-catenin-dependent signaling in mouse collecting duct cells. Am. J. Physiol. Renal. Physiol. 2015, 308, F358-F365. [CrossRef] [PubMed]

63. Tan, R.J.; Zhou, D.; Zhou, L.; Liu, Y. Wnt/beta-catenin signaling and kidney fibrosis. Kidney Int. 2014, 4 (Suppl. 2011), 84-90. [CrossRef]

64. DiRocco, D.P.; Kobayashi, A.; Taketo, M.M.; McMahon, A.P.; Humphreys, B.D. Wnt4/beta-catenin signaling in medullary kidney myofibroblasts. J. Am. Soc. Nephrol. 2013, 24, 1399-1412. [CrossRef] [PubMed]

65. Lin, S.L.; Li, B.; Rao, S.; Yeo, E.J.; Hudson, T.E.; Nowlin, B.T.; Pei, H.; Chen, L.; Zheng, J.J.; Carroll, T.J.; et al. Macrophage Wnt7b is critical for kidney repair and regeneration. Proc. Natl. Acad. Sci. USA 2010, 107, 4194-4199. [CrossRef]

66. Zhou, D.; Li, Y.; Lin, L.; Zhou, L.; Igarashi, P.; Liu, Y. Tubule-specific ablation of endogenous beta-catenin aggravates acute kidney injury in mice. Kidney Int. 2012, 82, 537-547. [CrossRef]

67. Nishikawa, K.; Osawa, Y.; Kimura, K. Wnt/beta-Catenin Signaling as a Potential Target for the Treatment of Liver Cirrhosis Using Antifibrotic Drugs. Int. J. Mol. Sci. 2018, 19, 3103. [CrossRef]

68. Okazaki, H.; Sato, S.; Koyama, K.; Morizumi, S.; Abe, S.; Azuma, M.; Chen, Y.; Goto, H.; Aono, Y.; Ogawa, H.; et al. The novel inhibitor PRI-724 for Wnt/beta-catenin/CBP signaling ameliorates bleomycin-induced pulmonary fibrosis in mice. Exp. Lung. Res. 2019, 45, 188-199. [CrossRef]

69. Ma, F.Y.; Sachchithananthan, M.; Flanc, R.S.; Nikolic-Paterson, D.J. Mitogen activated protein kinases in renal fibrosis. Front. Biosci. (Schol. Ed.) 2009, 1, 171-187. [CrossRef]

70. Sekine, S.; Nitta, K.; Uchida, K.; Yumura, W.; Nihei, H. Possible involvement of mitogen-activated protein kinase in the angiotensin II-induced fibronectin synthesis in renal interstitial fibroblasts. Arch. Biochem. Biophys. 2003, 415, 63-68. [CrossRef]

71. Grynberg, K.; Ma, F.Y.; Nikolic-Paterson, D.J. The JNK Signaling Pathway in Renal Fibrosis. Front. Physiol. 2017, 8, 829. [CrossRef] [PubMed]

72. Guo, B.; Inoki, K.; Isono, M.; Mori, H.; Kanasaki, K.; Sugimoto, T.; Akiba, S.; Sato, T.; Yang, B.; Kikkawa, R.; et al. MAPK/AP-1-dependent regulation of PAI-1 gene expression by TGF-beta in rat mesangial cells. Kidney Int. 2005, 68, 972-984. [CrossRef]

73. Wu, Y.; Wang, L.; Deng, D.; Zhang, Q.; Liu, W. Renalase Protects against Renal Fibrosis by Inhibiting the Activation of the ERK Signaling Pathways. Int. J. Mol. Sci. 2017, 18, 855. [CrossRef]

74. Ma, F.Y.; Flanc, R.S.; Tesch, G.H.; Han, Y.; Atkins, R.C.; Bennett, B.L.; Friedman, G.C.; Fan, J.H.; Nikolic-Paterson, D.J. A pathogenic role for c-Jun amino-terminal kinase signaling in renal fibrosis and tubular cell apoptosis. J. Am. Soc. Nephrol. 2007, 18, 472-484. [CrossRef] [PubMed]

75. Naito, T.; Masaki, T.; Nikolic-Paterson, D.J.; Tanji, C.; Yorioka, N.; Kohno, N. Angiotensin II induces thrombospondin-1 production in human mesangial cells via p38 MAPK and JNK: A mechanism for activation of latent TGF-beta1. Am. J. Physiol. Renal. Physiol. 2004, 286, F278-F287. [CrossRef] [PubMed]

76. Li, Z.; Liu, X.; Wang, B.; Nie, Y.; Wen, J.; Wang, Q.; Gu, C. Pirfenidone suppresses MAPK signalling pathway to reverse epithelial-mesenchymal transition and renal fibrosis. Nephrology (Carlton.) 2017, 22, 589-597. [CrossRef] [PubMed]

77. Davis, R.J. Signal transduction by the JNK group of MAP kinases. Cell 2000, 103, 239-252. [CrossRef]

78. Matsui, F.; Meldrum, K.K. The role of the Janus kinase family/signal transducer and activator of transcription signaling pathway in fibrotic renal disease. J. Surg. Res. 2012, 178, 339-345. [CrossRef]

79. Darnell, J.E., Jr.; Kerr, I.M.; Stark, G.R. Jak-STAT pathways and transcriptional activation in response to IFNs and other extracellular signaling proteins. Science 1994, 264, 1415-1421. [CrossRef]

80. Darnell, J.E., Jr. STATs and gene regulation. Science 1997, 277, 1630-1635. [CrossRef]

81. Bienaime, F.; Muorah, M.; Yammine, L.; Burtin, M.; Nguyen, C.; Baron, W.; Garbay, S.; Viau, A.; Broueilh, M.; Blanc, T.; et al. Stat3 Controls Tubulointerstitial Communication during CKD. J. Am. Soc. Nephrol. 2016, 27, 3690-3705. [CrossRef] [PubMed]

82. Berthier, C.C.; Zhang, H.; Schin, M.; Henger, A.; Nelson, R.G.; Yee, B.; Boucherot, A.; Neusser, M.A.; Cohen, C.D.; Carter-Su, C.; et al. Enhanced expression of Janus kinase-signal transducer and activator of transcription pathway members in human diabetic nephropathy. Diabetes 2009, 58, 469-477. [CrossRef] 
83. Yokota, T.; Omachi, K.; Suico, M.A.; Kamura, M.; Kojima, H.; Fukuda, R.; Motomura, K.; Teramoto, K.; Kaseda, S.; Kuwazuru, J.; et al. STAT3 inhibition attenuates the progressive phenotypes of Alport syndrome mouse model. Nephrol. Dial. Transplant. 2018, 33, 214-223. [CrossRef] [PubMed]

84. Zhou, L.; Fu, P.; Huang, X.R.; Liu, F.; Lai, K.N.; Lan, H.Y. Activation of p53 promotes renal injury in acute aristolochic acid nephropathy. J. Am. Soc. Nephrol. 2010, 21, 31-41. [CrossRef] [PubMed]

85. Lee, J.W.; Bae, E.; Kwon, S.H.; Yu, M.Y.; Cha, R.H.; Lee, H.; Kim, D.K.; Lee, J.P.; Ye, S.K.; Yoo, J.Y.; et al. Transcriptional modulation of the T helper 17/interleukin 17 axis ameliorates renal ischemia-reperfusion injury. Nephrol. Dial. Transplant. 2019, 34, 1481-1498. [CrossRef] [PubMed]

86. Nguyen, A.V.; Wu, Y.Y.; Liu, Q.; Wang, D.; Nguyen, S.; Loh, R.; Pang, J.; Friedman, K.; Orlofsky, A.; Augenlicht, L.; et al. STAT3 in epithelial cells regulates inflammation and tumor progression to malignant state in colon. Neoplasia 2013, 15, 998-1008. [CrossRef]

87. Reindl, W.; Weiss, S.; Lehr, H.A.; Forster, I. Essential crosstalk between myeloid and lymphoid cells for development of chronic colitis in myeloid-specific signal transducer and activator of transcription 3-deficient mice. Immunology 2007, 120, 19-27. [CrossRef]

88. Tuttle, K.R.; Brosius, F.C., III; Adler, S.G.; Kretzler, M.; Mehta, R.L.; Tumlin, J.A.; Tanaka, Y.; Haneda, M.; Liu, J.; Silk, M.E.; et al. JAK1/JAK2 inhibition by baricitinib in diabetic kidney disease: Results from a Phase 2 randomized controlled clinical trial. Nephrol. Dial. Transplant. 2018, 33, 1950-1959. [CrossRef]

89. Zhong, J.; Yang, H.C.; Fogo, A.B. A perspective on chronic kidney disease progression. Am. J. Physiol. Renal. Physiol. 2017, 312, F375-F384. [CrossRef]

90. Bonavia, A.; Singbartl, K. A review of the role of immune cells in acute kidney injury. Pediatr. Nephrol. 2018, 33, 1629-1639. [CrossRef]

91. Winterbourn, C.C.; Kettle, A.J.; Hampton, M.B. Reactive Oxygen Species and Neutrophil Function. Annu. Rev. Biochem. 2016, 85, 765-792. [CrossRef] [PubMed]

92. Rabadi, M.; Kim, M.; D'Agati, V.; Lee, H.T. Peptidyl arginine deiminase-4-deficient mice are protected against kidney and liver injury after renal ischemia and reperfusion. Am. J. Physiol. Renal. Physiol. 2016, 311, F437-F449. [CrossRef] [PubMed]

93. Nakazawa, D.; Marschner, J.A.; Platen, L.; Anders, H.J. Extracellular traps in kidney disease. Kidney Int. 2018, 94, 1087-1098. [CrossRef] [PubMed]

94. Singh, R.K.; Liang, D.; Gajjalaiahvari, U.R.; Kabbaj, M.H.; Paik, J.; Gunjan, A. Excess histone levels mediate cytotoxicity via multiple mechanisms. Cell Cycle 2010, 9, 4236-4244. [CrossRef]

95. Nakazawa, D.; Kumar, S.V.; Marschner, J.; Desai, J.; Holderied, A.; Rath, L.; Kraft, F.; Lei, Y.; Fukasawa, Y.; Moeckel, G.W.; et al. Histones and Neutrophil Extracellular Traps Enhance Tubular Necrosis and Remote Organ Injury in Ischemic AKI. J. Am. Soc. Nephrol. 2017, 28, 1753-1768. [CrossRef]

96. Liu, Y.J. Dendritic cell subsets and lineages, and their functions in innate and adaptive immunity. Cell 2001, 106, 259-262. [CrossRef]

97. Qian, C.; Cao, X. Dendritic cells in the regulation of immunity and inflammation. Semin. Immunol. 2018, 35, 3-11. [CrossRef]

98. Segura, E.; Amigorena, S. Inflammatory dendritic cells in mice and humans. Trends Immunol. 2013, 34, 440-445. [CrossRef]

99. Wang, R.; Chen, T.; Wang, C.; Zhang, Z.; Wang, X.M.; Li, Q.; Lee, V.W.S.; Wang, Y.M.; Zheng, G.; Alexander, S.I.; et al. Flt3 inhibition alleviates chronic kidney disease by suppressing CD103+ dendritic cell-mediated T cell activation. Nephrol. Dial. Transplant. 2019, 34, 1853-1863. [CrossRef]

100. Vivier, E.; Tomasello, E.; Baratin, M.; Walzer, T.; Ugolini, S. Functions of natural killer cells. Nat. Immunol. 2008, 9, 503-510. [CrossRef]

101. Vivier, E.; Nunes, J.A.; Vely, F. Natural killer cell signaling pathways. Science 2004, 306, 1517-1519. [CrossRef] [PubMed]

102. Bajenoff, M.; Breart, B.; Huang, A.Y.; Qi, H.; Cazareth, J.; Braud, V.M.; Germain, R.N.; Glaichenhaus, N. Natural killer cell behavior in lymph nodes revealed by static and real-time imaging. J. Exp. Med. 2006, 203, 619-631. [CrossRef]

103. Moretta, L.; Ferlazzo, G.; Bottino, C.; Vitale, M.; Pende, D.; Mingari, M.C.; Moretta, A. Effector and regulatory events during natural killer-dendritic cell interactions. Immunol. Rev. 2006, 214, 219-228. [CrossRef] [PubMed] 
104. Ikezumi, Y.; Hurst, L.; Atkins, R.C.; Nikolic-Paterson, D.J. Macrophage-mediated renal injury is dependent on signaling via the JNK pathway. J. Am. Soc. Nephrol. 2004, 15, 1775-1784. [CrossRef] [PubMed]

105. Schroder, K.; Sweet, M.J.; Hume, D.A. Signal integration between IFNgamma and TLR signalling pathways in macrophages. Immunobiology 2006, 211, 511-524. [CrossRef] [PubMed]

106. Wu, C.C.; Lee, J.; Raz, E.; Corr, M.; Carson, D.A. Necessity of oligonucleotide aggregation for toll-like receptor 9 activation. J. Biol. Chem. 2004, 279, 33071-33078. [CrossRef] [PubMed]

107. Ryu, M.; Kulkarni, O.P.; Radomska, E.; Miosge, N.; Gross, O.; Anders, H.J. Bacterial CpG-DNA accelerates Alport glomerulosclerosis by inducing an M1 macrophage phenotype and tumor necrosis factor-alpha-mediated podocyte loss. Kidney Int. 2011, 79, 189-198. [CrossRef]

108. Tomosugi, N.I.; Cashman, S.J.; Hay, H.; Pusey, C.D.; Evans, D.J.; Shaw, A.; Rees, A.J. Modulation of antibody-mediated glomerular injury in vivo by bacterial lipopolysaccharide, tumor necrosis factor, and IL-1. J. Immunol. 1989, 142, 3083-3090.

109. Timoshanko, J.R.; Sedgwick, J.D.; Holdsworth, S.R.; Tipping, P.G. Intrinsic renal cells are the major source of tumor necrosis factor contributing to renal injury in murine crescentic glomerulonephritis. J. Am. Soc. Nephrol. 2003, 14, 1785-1793. [CrossRef]

110. Tesch, G.H.; Yang, N.; Yu, H.; Lan, H.Y.; Foti, R.; Chadban, S.J.; Atkins, R.C.; Nikolic-Paterson, D.J. Intrinsic renal cells are the major source of interleukin-1 beta synthesis in normal and diseased rat kidney. Nephrol. Dial. Transplant. 1997, 12, 1109-1115. [CrossRef]

111. Han, Y.; Ma, F.Y.; Tesch, G.H.; Manthey, C.L.; Nikolic-Paterson, D.J. c-fms blockade reverses glomerular macrophage infiltration and halts development of crescentic anti-GBM glomerulonephritis in the rat. Lab. Investig. 2011, 91, 978-991. [CrossRef] [PubMed]

112. Kim, M.G.; Kim, S.C.; Ko, Y.S.; Lee, H.Y.; Jo, S.K.; Cho, W. The Role of M2 Macrophages in the Progression of Chronic Kidney Disease following Acute Kidney Injury. PLoS ONE 2015, 10, e0143961. [CrossRef] [PubMed]

113. Shen, B.; Liu, X.; Fan, Y.; Qiu, J. Macrophages regulate renal fibrosis through modulating TGFbeta superfamily signaling. Inflammation 2014, 37, 2076-2084. [CrossRef] [PubMed]

114. Rockey, D.C.; Bell, P.D.; Hill, J.A. Fibrosis-A common pathway to organ injury and failure. N. Engl. J. Med. 2015, 372, 1138-1149. [CrossRef]

115. Huen, S.C.; Cantley, L.G. Macrophage-mediated injury and repair after ischemic kidney injury. Pediatr. Nephrol. 2015, 30, 199-209. [CrossRef]

116. Lin, L.; Hu, K. Tissue-type plasminogen activator modulates macrophage M2 to M1 phenotypic change through annexin A2-mediated NF-kappaB pathway. Oncotarget 2017, 8, 88094-88103. [CrossRef]

117. Han, Y.; Ma, F.Y.; Tesch, G.H.; Manthey, C.L.; Nikolic-Paterson, D.J. Role of macrophages in the fibrotic phase of rat crescentic glomerulonephritis. Am. J. Physiol. Renal. Physiol. 2013, 304, F1043-F1053. [CrossRef]

118. Belliere, J.; Casemayou, A.; Ducasse, L.; Zakaroff-Girard, A.; Martins, F.; Iacovoni, J.S.; Guilbeau-Frugier, C.; Buffin-Meyer, B.; Pipy, B.; Chauveau, D.; et al. Specific macrophage subtypes influence the progression of rhabdomyolysis-induced kidney injury. J. Am. Soc. Nephrol. 2015, 26, 1363-1377. [CrossRef] [PubMed]

119. Klessens, C.Q.F.; Zandbergen, M.; Wolterbeek, R.; Bruijn, J.A.; Rabelink, T.J.; Bajema, I.M.; DHT, I.J. Macrophages in diabetic nephropathy in patients with type 2 diabetes. Nephrol. Dial. Transplant. 2017, 32, 1322-1329. [CrossRef]

120. Ikezumi, Y.; Suzuki, T.; Yamada, T.; Hasegawa, H.; Kaneko, U.; Hara, M.; Yanagihara, T.; Nikolic-Paterson, D.J.; Saitoh, A. Alternatively activated macrophages in the pathogenesis of chronic kidney allograft injury. Pediatr. Nephrol. 2015, 30, 1007-1017. [CrossRef]

121. Du, X.; Shimizu, A.; Masuda, Y.; Kuwahara, N.; Arai, T.; Kataoka, M.; Uchiyama, M.; Kaneko, T.; Akimoto, T.; Iino, Y.; et al. Involvement of matrix metalloproteinase- 2 in the development of renal interstitial fibrosis in mouse obstructive nephropathy. Lab. Investig. 2012, 92, 1149-1160. [CrossRef] [PubMed]

122. Henderson, N.C.; Mackinnon, A.C.; Farnworth, S.L.; Kipari, T.; Haslett, C.; Iredale, J.P.; Liu, F.T.; Hughes, J.; Sethi, T. Galectin-3 expression and secretion links macrophages to the promotion of renal fibrosis. Am. J. Pathol. 2008, 172, 288-298. [CrossRef] [PubMed]

123. Wang, S.; Meng, X.M.; Ng, Y.Y.; Ma, F.Y.; Zhou, S.; Zhang, Y.; Yang, C.; Huang, X.R.; Xiao, J.; Wang, Y.Y.; et al. TGF-beta/Smad3 signalling regulates the transition of bone marrow-derived macrophages into myofibroblasts during tissue fibrosis. Oncotarget 2016, 7, 8809-8822. [CrossRef]

124. Klingberg, F.; Hinz, B.; White, E.S. The myofibroblast matrix: Implications for tissue repair and fibrosis. J. Pathol. 2013, 229, 298-309. [CrossRef] 
125. Wang, Y.Y.; Jiang, H.; Pan, J.; Huang, X.R.; Wang, Y.C.; Huang, H.F.; To, K.F.; Nikolic-Paterson, D.J.; Lan, H.Y.; Chen, J.H. Macrophage-to-Myofibroblast Transition Contributes to Interstitial Fibrosis in Chronic Renal Allograft Injury. J. Am. Soc. Nephrol. 2017, 28, 2053-2067. [CrossRef]

126. LeBleu, V.S.; Taduri, G.; O'onnell, J.; Teng, Y.; Cooke, V.G.; Woda, C.; Sugimoto, H.; Kalluri, R. Origin and function of myofibroblasts in kidney fibrosis. Nat. Med. 2013, 19, 1047-1053. [CrossRef]

127. Fujimoto, M.; Maezawa, Y.; Yokote, K.; Joh, K.; Kobayashi, K.; Kawamura, H.; Nishimura, M.; Roberts, A.B.; Saito, Y.; Mori, S. Mice lacking Smad3 are protected against streptozotocin-induced diabetic glomerulopathy. Biochem. Biophys. Res. Commun. 2003, 305, 1002-1007. [CrossRef]

128. Moon, J.A.; Kim, H.T.; Cho, I.S.; Sheen, Y.Y.; Kim, D.K. IN-1130, a novel transforming growth factor-beta type I receptor kinase (ALK5) inhibitor, suppresses renal fibrosis in obstructive nephropathy. Kidney Int. 2006, 70, 1234-1243. [CrossRef]

129. Wang, J.; Zhuang, S. Src family kinases in chronic kidney disease. Am. J. Physiol. Renal. Physiol. 2017, 313, F721-F728. [CrossRef]

130. Tang, P.M.; Zhou, S.; Li, C.J.; Liao, J.; Xiao, J.; Wang, Q.M.; Lian, G.Y.; Li, J.; Huang, X.R.; To, K.F.; et al. The proto-oncogene tyrosine protein kinase $\mathrm{Src}$ is essential for macrophage-myofibroblast transition during renal scarring. Kidney Int. 2018, 93, 173-187. [CrossRef]

131. Wiseman, A.C. Immunosuppressive Medications. Clin. J. Am. Soc. Nephrol. 2016, 11, 332-343. [CrossRef] [PubMed]

132. Praga, M.; Barrio, V.; Juarez, G.F.; Luno, J.; Grupo Espanol de Estudio de la Nefropatia Membranosa. Tacrolimus monotherapy in membranous nephropathy: A randomized controlled trial. Kidney Int. 2007, 71, 924-930. [CrossRef] [PubMed]

133. Faul, C.; Donnelly, M.; Merscher-Gomez, S.; Chang, Y.H.; Franz, S.; Delfgaauw, J.; Chang, J.M.; Choi, H.Y.; Campbell, K.N.; Kim, K.; et al. The actin cytoskeleton of kidney podocytes is a direct target of the antiproteinuric effect of cyclosporine A. Nat. Med. 2008, 14, 931-938. [CrossRef] [PubMed]

134. Braun, N.; Schmutzler, F.; Lange, C.; Perna, A.; Remuzzi, G.; Risler, T.; Willis, N.S. Immunosuppressive treatment for focal segmental glomerulosclerosis in adults. Cochrane Database Syst. Rev. 2008, CD003233. [CrossRef] [PubMed]

135. Larsen, C.P.; Pearson, T.C.; Adams, A.B.; Tso, P.; Shirasugi, N.; Strobert, E.; Anderson, D.; Cowan, S.; Price, K.; Naemura, J.; et al. Rational development of LEA29Y (belatacept), a high-affinity variant of CTLA4-Ig with potent immunosuppressive properties. Am. J. Transplant. 2005, 5, 443-453. [CrossRef]

136. Maxwell, L.; Singh, J.A. Abatacept for rheumatoid arthritis. Cochrane Database Syst. Rev. 2009, CD007277. [CrossRef]

137. Salama, A.D.; Pusey, C.D. Drug insight: Rituximab in renal disease and transplantation. Nat. Clin. Pract. Nephrol. 2006, 2, 221-230. [CrossRef]

138. Manzi, S.; Sanchez-Guerrero, J.; Merrill, J.T.; Furie, R.; Gladman, D.; Navarra, S.V.; Ginzler, E.M.; D'Cruz, D.P.; Doria, A.; Cooper, S.; et al. Effects of belimumab, a B lymphocyte stimulator-specific inhibitor, on disease activity across multiple organ domains in patients with systemic lupus erythematosus: Combined results from two phase III trials. Ann. Rheum. Dis. 2012, 71, 1833-1838. [CrossRef]

139. Gaballa, M.R.; Laubach, J.P.; Schlossman, R.L.; Redman, K.; Noonan, K.; Mitsiades, C.S.; Ghobrial, I.M.; Munshi, N.; Anderson, K.C.; Richardson, P.G. Management of myeloma-associated renal dysfunction in the era of novel therapies. Expert. Rev. Hematol. 2012, 5, 51-66, quiz 67-68. [CrossRef]

140. Zhuang, Q.; Ma, R.; Yin, Y.; Lan, T.; Yu, M.; Ming, Y. Mesenchymal Stem Cells in Renal Fibrosis: The Flame of Cytotherapy. Stem. Cells Int. 2019, 2019, 8387350. [CrossRef]

141. Kuppe, C.; Kramann, R. Role of mesenchymal stem cells in kidney injury and fibrosis. Curr. Opin. Nephrol. Hypertens. 2016, 25, 372-377. [CrossRef] [PubMed]

142. Rota, C.; Morigi, M.; Cerullo, D.; Introna, M.; Colpani, O.; Corna, D.; Capelli, C.; Rabelink, T.J.; Leuning, D.G.; Rottoli, D.; et al. Therapeutic potential of stromal cells of non-renal or renal origin in experimental chronic kidney disease. Stem. Cell Res. Ther. 2018, 9, 220. [CrossRef] [PubMed]

143. Togel, F.; Cohen, A.; Zhang, P.; Yang, Y.; Hu, Z.; Westenfelder, C. Autologous and allogeneic marrow stromal cells are safe and effective for the treatment of acute kidney injury. Stem. Cells Dev. 2009, 18, 475-485. [CrossRef] [PubMed] 
144. Huuskes, B.M.; Wise, A.F.; Cox, A.J.; Lim, E.X.; Payne, N.L.; Kelly, D.J.; Samuel, C.S.; Ricardo, S.D. Combination therapy of mesenchymal stem cells and serelaxin effectively attenuates renal fibrosis in obstructive nephropathy. FASEB J. 2015, 29, 540-553. [CrossRef] [PubMed]

145. Alatab, S.; Shekarchian, S.; Najafi, I.; Moghadasali, R.; Ahmadbeigi, N.; Pourmand, M.R.; Bolurieh, T.; Jaroughi, N.; Pourmand, G.; Aghdami, N. Systemic Infusion of Autologous Adipose Tissue-Derived Mesenchymal Stem Cells in Peritoneal Dialysis Patients: Feasibility and Safety. Cell J. 2019, 20, 483-495. [CrossRef] [PubMed]

146. Brudno, J.N.; Kochenderfer, J.N. Chimeric antigen receptor T-cell therapies for lymphoma. Nat. Rev. Clin. Oncol. 2018, 15, 31-46. [CrossRef]

147. Neelapu, S.S.; Tummala, S.; Kebriaei, P.; Wierda, W.; Gutierrez, C.; Locke, F.L.; Komanduri, K.V.; Lin, Y.; Jain, N.; Daver, N.; et al. Chimeric antigen receptor T-cell therapy-Assessment and management of toxicities. Nat. Rev. Clin. Oncol. 2018, 15, 47-62. [CrossRef]

148. Gupta, S.; Seethapathy, H.; Strohbehn, I.A.; Frigault, M.J.; O’Donnell, E.K.; Jacobson, C.A.; Motwani, S.S.; Parikh, S.M.; Curhan, G.C.; Reynolds, K.L.; et al. Acute Kidney Injury and Electrolyte Abnormalities After Chimeric Antigen Receptor T-Cell (CAR-T) Therapy for Diffuse Large B-Cell Lymphoma. Am. J. Kidney Dis. 2020. [CrossRef]

149. Kitching, A.R.; Jaw, J. Chimeric antigen receptor T (CAR T) cells: Another cancer therapy with potential applications in kidney disease and transplantation? Kidney Int. 2018, 94, 4-6. [CrossRef]

150. Hosoi, T.; Okuma, Y.; Matsuda, T.; Nomura, Y. Novel pathway for LPS-induced afferent vagus nerve activation: Possible role of nodose ganglion. Auton. Neurosci. 2005, 120, 104-107. [CrossRef]

151. Rosas-Ballina, M.; Ochani, M.; Parrish, W.R.; Ochani, K.; Harris, Y.T.; Huston, J.M.; Chavan, S.; Tracey, K.J. Splenic nerve is required for cholinergic antiinflammatory pathway control of TNF in endotoxemia. Proc. Natl. Acad. Sci. USA 2008, 105, 11008-11013. [CrossRef]

152. Wang, H.; Yu, M.; Ochani, M.; Amella, C.A.; Tanovic, M.; Susarla, S.; Li, J.H.; Wang, H.; Yang, H.; Ulloa, L.; et al. Nicotinic acetylcholine receptor alpha7 subunit is an essential regulator of inflammation. Nature 2003, 421, 384-388. [CrossRef]

153. Gigliotti, J.C.; Huang, L.; Bajwa, A.; Ye, H.; Mace, E.H.; Hossack, J.A.; Kalantari, K.; Inoue, T.; Rosin, D.L.; Okusa, M.D. Ultrasound Modulates the Splenic Neuroimmune Axis in Attenuating AKI. J. Am. Soc. Nephrol. 2015, 26, 2470-2481. [CrossRef] [PubMed]

154. Gigliotti, J.C.; Huang, L.; Ye, H.; Bajwa, A.; Chattrabhuti, K.; Lee, S.; Klibanov, A.L.; Kalantari, K.; Rosin, D.L.; Okusa, M.D. Ultrasound prevents renal ischemia-reperfusion injury by stimulating the splenic cholinergic anti-inflammatory pathway. J. Am. Soc. Nephrol. 2013, 24, 1451-1460. [CrossRef]

155. Ribes, D.; Casemayou, A.; El Hachem, H.; Laurent, C.; Guilbeau-Frugier, C.; Vergez, F.; Tavitian, S.; Schanstra, J.P.; Chauveau, D.; Bascands, J.L.; et al. Asymptomatic circulating T-cell clone cause renal polymorphic inflammatory fibrosis. Clin. Exp. Nephrol. 2017, 21, 781-786. [CrossRef]

156. Wen, Y.; Rudemiller, N.P.; Zhang, J.; Jeffs, A.D.; Griffiths, R.; Lu, X.; Ren, J.; Privratsky, J.; Crowley, S.D. Stimulating Type 1 Angiotensin Receptors on T Lymphocytes Attenuates Renal Fibrosis. Am. J. Pathol. 2019, 189, 981-988. [CrossRef]

157. Han, H.; Zhu, J.; Wang, Y.; Zhu, Z.; Chen, Y.; Lu, L.; Jin, W.; Yan, X.; Zhang, R. Renal recruitment of B lymphocytes exacerbates tubulointerstitial fibrosis by promoting monocyte mobilization and infiltration after unilateral ureteral obstruction. J. Pathol. 2017, 241, 80-90. [CrossRef] [PubMed]

158. Jansen, M.P.; Emal, D.; Teske, G.J.; Dessing, M.C.; Florquin, S.; Roelofs, J.J. Release of extracellular DNA influences renal ischemia reperfusion injury by platelet activation and formation of neutrophil extracellular traps. Kidney Int. 2017, 91, 352-364. [CrossRef]

159. Kumar, S.V.; Kulkarni, O.P.; Mulay, S.R.; Darisipudi, M.N.; Romoli, S.; Thomasova, D.; Scherbaum, C.R.; Hohenstein, B.; Hugo, C.; Muller, S.; et al. Neutrophil Extracellular Trap-Related Extracellular Histones Cause Vascular Necrosis in Severe GN. J. Am. Soc. Nephrol. 2015, 26, 2399-2413. [CrossRef] [PubMed]

160. Westhorpe, C.L.; Bayard, J.E.; O’Sullivan, K.M.; Hall, P.; Cheng, Q.; Kitching, A.R.; Hickey, M.J. In Vivo Imaging of Inflamed Glomeruli Reveals Dynamics of Neutrophil Extracellular Trap Formation in Glomerular Capillaries. Am. J. Pathol. 2017, 187, 318-331. [CrossRef] [PubMed]

161. Cao, Q.; Lu, J.; Li, Q.; Wang, C.; Wang, X.M.; Lee, V.W.; Wang, C.; Nguyen, H.; Zheng, G.; Zhao, Y.; et al. CD103+ Dendritic Cells Elicit CD8+ T Cell Responses to Accelerate Kidney Injury in Adriamycin Nephropathy. J. Am. Soc. Nephrol. 2016, 27, 1344-1360. [CrossRef] [PubMed] 
162. Spada, R.; Rojas, J.M.; Perez-Yague, S.; Mulens, V.; Cannata-Ortiz, P.; Bragado, R.; Barber, D.F. NKG2D ligand overexpression in lupus nephritis correlates with increased NK cell activity and differentiation in kidneys but not in the periphery. J. Leukoc. Biol. 2015, 97, 583-598. [CrossRef] [PubMed]

163. Zhang, Z.X.; Wang, S.; Huang, X.; Min, W.P.; Sun, H.; Liu, W.; Garcia, B.; Jevnikar, A.M. NK cells induce apoptosis in tubular epithelial cells and contribute to renal ischemia-reperfusion injury. J. Immunol. 2008, 181, 7489-7498. [CrossRef] [PubMed]

164. Meng, X.M.; Wang, S.; Huang, X.R.; Yang, C.; Xiao, J.; Zhang, Y.; To, K.F.; Nikolic-Paterson, D.J.; Lan, H.Y. Inflammatory macrophages can transdifferentiate into myofibroblasts during renal fibrosis. Cell Death Dis. 2016, 7, e2495. [CrossRef]

(C) 2020 by the authors. Licensee MDPI, Basel, Switzerland. This article is an open access article distributed under the terms and conditions of the Creative Commons Attribution (CC BY) license (http://creativecommons.org/licenses/by/4.0/). 